\title{
Some Features of the Legislative Process in the Parliaments of the Asia-Pacific Region
}

\author{
Victor Afanasevich Shekhovtcov \\ Ekaterina Dmitrievna Evseenko \\ Far Eastern Federal University \\ parlament6348@mail.ru, evseenko.lawyer@gmail.com
}

\section{Doi:10.5901/mjss.2015.v6n3s6p295}

\section{Abstract}

\begin{abstract}
In the article reveals specific features of the legislative process in the parliaments of the Pacific Rim. Russian relations development with these countries causes the need of studying of their legal systems, positive experience of effective regulation of the public relations in legislative activity. The legislative process is one of the main constitutional and legal institutions of the modern state, regardless of its form of government, government, political regime. The law creation process is carefully regulated and strictly formalized. It concerns to both procedure and a form of acts. The legislative process is defined as system of proceedings and actions of which creation of the law is the result. Traditionally, this process is the isolated stage of the legislative initiative, consideration, and adoption of the draft bill chambers of parliament, the promulgation of the law. The comparative and legal analysis of legislative process stages in parliaments of the Pacific Rim countries allows revealing and estimating their difference on subject structure, the contents, procedures, periods and some other essential characteristics. Expansion of political, economic, cultural and other connections between Russia and the Pacific Rim states leads to legal mechanisms, procedural partnership optimization rules creation and development. The conclusions received by authors have undoubted value for efficiency increase of legislative process as studying of its separate features, loan of positive experience taking into account peculiar characteristics of the concrete state can become the major step on the way of legislative activity improvement of parliaments.
\end{abstract}

Keywords: the legislative process, Pacific Rim, parliament, head of state, veto.

\section{Introduction}

In the last thirty years which passed since the beginning of so-called "reorganization" in the Russian science of a constitutional right there is a revision of some theoretical regulations on essence of the state, questions of the organization and activity of public authorities. In addition, in the Constitution of the Russian Federation of 1993, and the principle of division of the authorities, multi-party system, parliament and parliamentary and democratic procedures of the legislative process found fixing in real life.

Russian partnership development with the countries of the Pacific Rim (PR) causes the need of studying of their legal systems. The judgment of the new legal phenomena, the main regularities allows making use of the latest foreign experience in realities of the Russian state.

In the modern world integration processes amplify, interest in studying and mutual use of national legislations experience development, to an exchange of legal information and scientific ideas increases (Tikhomirov, 1996, p. 5). The particular interest gets studying of experience of an institutionalization of institutes of the government in the Pacific Rim countries.

The legislative process is one of the main constitutional and legal institutes of the modern state regardless of its form of government, a state system, a political regime.

Division of the authorities in the legislative process plays a particular role. As noted the Constitutional Court of the Russian Federation in the Resolution of April 22, 1986 No. 10-P, according to Art. 94, p.1 Art. 95, Art. 104-108 of the Constitution of the Russian Federation the Federation Council and the State Duma, and the President of Russia, other government bodies, and persons participate in the implementation of the legislative function. Thus, all participants are obliged to observe the lawmaking procedure established by the Constitution to the Russian Federation.

In the Resolution of January 18, 1996 No. 2-P the Constitutional Court of Russia noted that the Constitution of the Russian Federation refers adoption of laws to exclusive maintaining legislature. At the same time, it provides the veto and promulgation (signing and publication) of federal legislation by the head of state as an essential element of the legislative 
procedure providing division of the authorities as a guarantee from possible mistakes. As a result, the law adopted by parliament finds the force of the legal act of the uniform government (Avakyan, 2014, p. 372).

Studying of constitutional and legal regulation of various aspects of the legislative process in Pacific Rim can promote the introduction of the approved, effective organizational forms, methods and procedures in parliament activity.

\section{Research Methods}

While studying of many-sided laws creation process- normative legal acts of the highest validity, methods have the defining value: comparative and legal; the historical; systemic-functional and some other methods of scientific knowledge.

The real comparative and legal research has the result studying, and comparison of a current state of one of the most important democratic institutes of the Pacific Rim states - legislative process. Authors analyze some features of the considered institute within separately taken legislative process stages.

As, as we know, criterion of truth - the practician, optimization of legislative process requires detailed studying of various parties, characteristics of activity of parliaments and legislators of the countries with different levels of the constitutional and parliamentary development, history and traditions.

\section{Literature Review}

\subsection{Legislative initiative}

In the most general view, the legislative process is defined as a system of procedures and actions of which creation of the law is the result (Avakyan, 2015, p. 297). In jurisprudence, there is no uniform approach to the allocation of stages legislative process (Aleman, 2003). Traditionally distinguish stages of the legislative initiative, consideration, and adoption of the draft law chambers of parliament, the promulgation and publication of the law.

The first stage of the legislative process calls entering of the bill into parliament. The stage of the legislative initiative is fixed in-laws of all of the Pacific Rim states without any exception.

The constitutional legal status element as the legislative initiative represents the right of an appropriate subject for official entering into Parliament of the bill. In the Russian Federation, it can also be realized in the form of entering into the lower house of amendments parliament to the bills, which are already under consideration of chamber.

In the majority of the states of Pacific Rim among the subjects having rights of a legislative initiative traditionally, call parliamentarians and the government. In a number of constitutions, it is possible to find other topics: government bodies of the highest and subordinate level (for example, Mexico, Russian Federation), public institutions and organizations (Kingdom of Thailand), other open formations (Republic of Peru, Vietnam), groups of voters (for example, Colombia). In the United States of America, bills have rights to bring only members of chambers of Parliament. An exception - the draft budget that is submitted the President.

Practically in all states of the considered region, the circle of subjects of a legislative initiative joins the government (The Russian Federation, Indonesia, Thailand, Colombia, etc.). In some cases as such subject, not the government, but the head of an executive branch of the power (Article 72 of the Constitution of Japan) is called. Visually this fact is traced in the countries with the developed system of parliamentary founded on the mechanism of formation of the government of the parliamentary majority, in these cases the legislative initiative is realized actually only by executive power.

In the classical presidential republic - the USA the head of state formally has no the right of a legislative initiative. The constitution of the United States of America grants this right only to the country supreme legislative body - to the Congress, to be exact, to members of both of its chambers (Sakharov, 1994, p. 109). Meanwhile, without being the legislative initiative subject, the U.S. President can realize it an indirect way through messages to the Congress which quite often are the guide to action for parliamentarians of presidential party, inducing them to act formally with the personal initiative.

For the countries of Latin America with a presidential government, it is characteristic both broad application of messages to Parliament, and active use of the head of state of the right of a legislative initiative. The president of Mexico when opening regular session of the Congress does the report on the position of the country. "In this document - the Mexican lawyer Moreno Sanchez writes - obligatory instructions for the Congress by which it is compelled to be guided at adoption of laws" (Moreno, 1974, p contain. 38).

Along with messages, an exclusive prerogative of the head of state there is an introduction of bills concerning the budget of the country (Mexico, the USA, Thailand, etc.).

As for the upper houses of parliaments of the Pacific Rim, not all of them are allocated with the right of legislative 
initiative. Thus you should not mix powers on introduction of the bill by actually upper house, as, for example, in Japan or Russia, and the right of a legislative initiative of her certain members (the USA, Mexico). In some countries, for example in Canada, the called right of the upper house is limited to procedural features, and the list of questions on which this chamber can take the legislative initiative.Such restrictions concern the budgetary, tax issues and international treaties ratification questions.

The special place among legal entities of a legislative initiative is assigned for the population of the states of Pacific Rim. The popular legislative initiative represents the right of a certain group of voters to offer the bill, which is subject to obligatory consideration by parliament.

For the first time in a modern look, the institute of a popular legislative initiative appears in the United States of America in connection with adoption in 1715 of the law of the State of Massachusetts, which affirmed the right of the population to put forward the relevant initiatives at the local level. Now in Pacific Rim the institute of a popular legislative initiative operates on the state level in Peru, Colombia, on Philippines, at the regional level - in 24 American states, in certain subjects of the Russian Federation.

The possibility of realization by the people of the right is limited a number of the procedural conditions concerning number of the participating voters, the petition of citizens, check of their authenticity. In Peru for the introduction of the bill it is necessary to collect not less than 50 thousand signatures of voters. Thus on a number of questions the popular legislative initiative cannot be carried out. On the contrary, the Constitution of the Republic of Colombia of 1991 does not fix such restriction of realization by citizens of a legislative initiative: the bill can be submitted to the number equal or exceeding $5 \%$ of total number of the voters registered for the corresponding date (Text of constitution of Colombia 1991). The Congress considers such projects quickly, and the citizens who took the initiative can appoint the representative who will listen with delight to chambers at all stages of passing of the bill.

The consolidated legislative initiatives have interregional character. They are one of the mechanisms of interaction of the Federation in the legislative process aimed at improving the quality of laws. The analysis of experience of federations of the Pacific Rim (the Australian Union, Canada, the USA, and India) shows, that the consolidated legislative initiative is the unique particular form, which gained the distribution only in the Russian Federation.

The bills introduction procedure in some countries is simplest. In the United States in the House of Representatives, the bill falls into a particular box, in the Senate the act of introduction is followed by the short speech of the document author. In the Indian Parliament, the introduction of the bill only in rare instances is followed by a short debate.

At the same time, the constitutional right of a collective legislative initiative of deputies is often affirmed. In Japan the parliamentarian, wishing to introduce the bill, has to be written support of 10 advisers or 20 representatives, to accompany the offered document with written justification, to observe established periods of giving. Draft budgets require the minimum support of 20 advisers or 50 representatives. The requirement of a group initiative is caused mainly by fractional dissociation of chambers of Japanese parliament. However, despite certain difficulties, a similar order has a number of advantages. It promotes "amateur" bills number reduction, strengthens a sense of legislators responsibility.

The Constitution of the People's Republic of China is no section about the introduction of bills in the legislature. The exhaustive list of the bodies and persons having rights of a legislative initiative is given in the Law on the organization of the National People's Congress according to which the bill can be introduced not less than 30 deputies or delegation, that is group of deputies from one selective unit (The law People's Republic of China "About elections to the National People's Congress and to local meetings of national representatives of various steps").

\subsection{The bill consideration and adoption}

The second stage of legislative process - consideration of the draft law by parliament chambers. Each stage of discussion of the bill comes to the end with the adoption of this or that decision that is a documentary made out.

Let's notice that the foreign countries majority the rules limiting a freedom of speech of parliamentarians are applied. Therefore, in the USA according to the procedural rule "kangaroo" the Speaker himself resolves an issue of what of the offered amendments will be put to discussion and vote. Besides, there is a number of ways of restriction of debate and acceleration of passing of the bill: transformation of chamber to "committee of all chamber on position of the Union", restriction of duration of discussion by the Chairman of chamber, termination of debate by the order of the leading committee. The speaker has the right to reject any offer as "the tightening (delaying) vote", to specify to the chamber that it "deviates hearing of cases". In the House of Representatives, the "preliminary question" borrowed from English practice - debate closing is often applied. Unlike the lower house of debate in the Senate can be closed on request of 3/5 senators. Thanks to this feature in the Senate prospers "filibustering ". Opponents of the bill, using the discontinuity 
principle, can fail the bill, making long speeches. Therefore, Senator Bilbo in 1944 spoke within two days.

Debate restrictions in the parliamentary practice of India - a common phenomenon. The discussion on the bill is limited to contents of the report and the basic bill principles. A similar practice is applied in the Japanese parliament.

The most important stage of this phase is the bill consideration by committees. The most typical in this regard is the committee system of the USA where the primary activity of chambers of the Congress is carried out dependently, and by means of the numerous constantly operating committees. Unlike American, legislative committees of the Pacific Rim parliament's majority do not usurp chamber power and play a role of subsidiary bodies.

A peculiar system works in parliament of India. Before adoption of the Constitution of 1950 in the Legislative Assembly of India, there were standing consultative committees, which were created according to the nomenclature (range) of the ministries, and, they were served. Modern committees of the Indian parliament are subsidiary organs of chambers and work strictly according to their recommendations.

The considered stage comes to the end with itemized vote and adoption of the law. In parliamentary practice of Pacific Rim countries are applied various ways of vote: "division" (the USA, India), by name, a raising of hands (Chile, Peru), by means of bulletins (Canada), electronic machines (Russia, the USA).

\subsection{Promulgation and publication of the law}

The legislative process comes to the end with signing, publication and introduction of the law to action. The maintenance of the considered stage is that the law adopted by chambers of parliament goes for signing to the head of state.

Most of heads of Pacific Rim countries at a stage of promulgation are allocated with the veto - an efficient remedy of impact on the legislature. The absolute veto consists that the refusal of the head of state to approve the bill adopted by parliament is final, unconditional, and it is impossible to overcome it (Baglay, 2013, p. 230). Now the monarch of Great Britain has such rights. However, the absolute veto is only registered in an arsenal of prerogatives of the monarch but is not applied. Legally it exists; stays in a condition of a long lethargically sleep (Mishin, 2013, p. 224).

The relative veto represents the ban of the head of state imposed by the law, which can be overcome by parliament. The relative veto can be overcome simple (for example, in Peru) or qualified by a majority vote from total number of parliamentarians (the Russian Federation, Mexico, etc.). Practice shows that in the latter case to overcome the veto of the head of the state difficulty. In the USA practically for all history of existence from 1405 vetoes of the President it was overcome only in 110 cases (Chirkin, 2014, p. 32) because in each of chambers of the Congress often it is not collected 2/3 votes, necessary for overcoming of the veto. "Champion" among U.S. Presidents was F. D. Roosevelt who used this right of 635 times, and only in 9 cases of its veto was overcome by the Congress (Kenenova, 2014).

The selective veto is the right of the head of state to protest only separate articles, approving the bill in general. The constitution of Philippines provides that the President be authorized to veto any article about allocations, the income, and duties, thus the ban does not influence other articles concerning which it was not stated objections (the Constitution of the Republic of Philippines). In Russia, it is hard to call the veto selective as the Constitution of the Russian Federation speaks about the right of the President to reject the law, but not its separate articles. At the same time, as the practice of realization of this power shows, the President cannot agree both with the law in general, and with its separate situation.

One more look - "the pocket veto" originates in the presidential practice of the United States of America. When until the end of parliamentary session of the Congress of the USA there are less than 10 days, the head of state cannot sign the bill therefore at the Congress does not remain temporary opportunities for carrying out repeated vote, the law rejects, at least, before the following session of Parliament. The legislative practice of the United States knows many cases of the application by the head of state of "the pocket veto" (Gicquel \& Gicquel, 2011). In the American history during the period from 1789 to 2010 about 1100 cases of its application by U.S. Presidents are.

After signing by the head of state, laws are subject to official publication. The value of this procedure is that not published laws are not applied (part 3 of article 15 of the Constitution of the Russian Federation). As a result, the law enters into force after the deadline from the date of his official publication, unless the law or the act of putting it into effect otherwise noted.

\section{Results and Discussions}

The legislative process in a narrow sense represents an order of entering into Parliament of bills, their discussions, acceptance and publication of laws. The law creation process in foreign countries is carefully regulated and strictly formalized. It concerns both the procedure, and a form of acts.

Each stage of the legislative process is characterized by own subject structure, the contents, periods and some 
other essential characteristics.

The first stage of the legislative process is entering of the bill into parliament or otherwise - a stage of a legislative initiative. In a narrow sense, the legislative initiative represents the right of the subject for the official introduction of the bill. Depending on features of a state system, political practice and legal traditions of the constitution of foreign countries define a various circle of legislative initiative subjects. Besides legislators, the commissions and committees of parliament, it can include the government, the head of state, subjects of the federation, voters, political parties, public organizations and others. In our opinion, excessive expansion, as well as unreasonable restriction of the legislative initiative subjects list are extremes, which it is necessary to avoid.

The world practice recognizes that heads of states usually are not among subjects of a legislative initiative. In this regard, the experience of the countries of the Pacific Rim is unique. According to Art. 71 of the Constitution of the United Mexican States the legislative initiative right belongs to the President, deputies and senators of the Federal Congress, legislature of states. Similar norms contain in basic laws of Russia, Chile, Peru, Indonesia.

In the countries of the Pacific Rim region the alternative form of legislative initiatives realization in the form of bills that are introduced by individual MPs, but on behalf of the President, brought by certain deputies, but at the request of the president is known. Such bills, as a rule, are accepted by Parliament. Similar legislative initiatives make about $40 \%$ of all bills introduced in the Mexican Congress (Gonsales, 1974, p. 82).

At a stage of consideration of the bill by chambers of parliament, transferring of the center of gravity from plenary sessions in committees that is explained by the change of nature of the activity of modern parliaments is observed. In our opinion, any parliament of the modern state cannot work without the aid of standing committees, which, however, should not turn into establishing standards bodies.

Power to sign; approves the normative legal acts adopted by parliament having the highest validity belongs to heads of states of the Pacific Rim. The role of the head of state at a stage of publication and the previous actions for promulgation consists "in certification of authenticity of the text of the act or its authenticity with the original" (Torop, 2009, p. 144). Signing the law, he notes thereby that this law is adopted by parliament correctly and is subject to obligatory execution after its publication and coming into effect.

Most of heads of Pacific Rim countries at a stage of promulgation are allocated with the veto - an efficient remedy of impact on the legislature. Recently the tendency of active use by presidents of the veto was outlined in the countries of the Pacific Rim. Therefore, the President of Mexico Adolfo López Mateos for years of stay in power vetoed 14 bills. The president Gustavo Díaz Ordaz Bolaños, who replaced him on this post, used the veto 23 times (Gonsales, 1974).

In some countries (Japan, the People's Republic of China) the veto of the head is not affirmed, however the law has to be approved by them. Here direct dependence between existence or absence of such right and the form of government is traced a political regime of the country.

\section{Conclusion}

In modern conditions of the intensive lawmaking caused by legislative initiatives variety, the high value gets identification of the valid need for adoption of the concrete act. Thus key are questions of the efficiency of the adopted laws. The culture and level of the legislative process, and respectively and quality of the adopted laws - is an indicator of the civilization of society and democratic character of the state.

Expansion of political, economic, cultural and other connections between Russia and the countries of the Pacific Rim leads to creation and development of legal mechanisms, procedural rules of optimization of partnership. First, it concerns the standard regulation of all spheres of interaction by means of the adoption of qualitative and efficient laws. Studying of separate features of legislative process of parliaments of Pacific Rim countries, loan of positive experience taking into account peculiar characteristics of each concrete state can become the major step on the way of improvement of legislative activity of parliaments.

The accounting of experience of the states of the Pacific Rim, and precepts of law which proved the expediency and efficiency in foreign practice, in our opinion, can promote improvement of process of creation of the law in Russia and other countries.

\section{References}

Aleman, E. (2003). Legislative rules and the amending process in Argentina, Chile and Mexico: theory and evidence. California: UCLA. Gicquel, J., \& Gicquel, J.-É. (2011). Droit constitutionnel et institutionspolitiques (изд. 25-éd. Р.).

Gonsales, C. P. (1974). La democracia en Mexico. Mexico. 
Moreno, S. (1974). Crisis polîtica de Mexico. Mexico.

The text of Constitution of Colombia 1991. It is received from http://confinder.richmond.edu/admin/docs/colombia_const2.pdf

Avakyan, S. A. (2015). Constitutional lexicon: state and legal terminological dictionary. Moscow: Yustitsinform.

Avakyan, S. A. (2014). Modern problems of the organization of the public power. Moscow: Yustitsinform.

Baglay, M. V. (2013). The constitutional right of foreign countries. Moscow: Norma.

The law People's Republic of China "About elections to the National People's Congress and local meetings of national representatives of various steps". It is received from http://chinalawinfo.ru/constitutional_law/law_npc_elections-2

Zimmerman, D. (1991). Direct democracy in the United States of America: experience and problems. Bulletin of MSU. Ser. "Pravo" (5), 52-53.

Kenenova, I. P. (2014). The organization of the government and division of the authorities in the USA. In the book "The Organization of the Government in Russia and Foreign Countries". Moscow: Yustitsinform.

Constitution of the Republic of Philippines. It is received from http:// worldconstitutions.ru/?p=36.

Mishin, A. A. (2013). Constitutional (state) right of foreign countries (17th edition). Moscow.

Sakharov, N. A. (1994). Institute of the presidency in the modern world. Moscow: Legal literature.

Tikhomirov, Yu. A. (1996). The course of comparative jurisprudence. Moscow: NORMA.

Torop, Yu. V. (2009). Features of promulgation and publication of the law as stages of the legislative process in parliamentary federal states of Western Europe. Russian legal magazine (6), 141-149.

Chirkin, V. E. (2014). About terminology accuracy concerning the adoption of the law. Journal of Russian law. 